Acta Theriologica 45, Suppl. 1: 79-91, 2000.

PL ISSN 0001-7051

\title{
Genetic differentiation and gene flow between the Drnholec and Łęgucki Mlyn chromosome races of the common shrew Sorex araneus in northern Poland
}

\author{
Mirosław RATKIEWICZ, Joanna SUPRUNIUK, Stanisław FEDYK, \\ Agata BANASZEK, Włodzimierz CHĘTNICKI and Katarzyna A. SZAŁAJ
}

Ratkiewicz M., Supruniuk J., Fedyk S., Banaszek A., Chętnicki W. and Szałaj K. A. 2000. Genetic differentiation and gene flow between the Drnholec and Łẹgucki Młyn chromosome races of the common shrew Sorex araneus in northern Poland. [In: Evolution in the Sorex araneus group: Cytogenetic and molecular aspects. J. B. Searle and J. M. Wójcik, eds]. Acta Theriologica 45, Suppl. 1: 79-91.

Genetic variability at 31 enzyme loci in five populations of the common shrews Sorex araneus Linnaeus, 1758 from the hybrid zone between the Drnholec (Dn) and Łegucki Młyn ( $\mathrm{kg}$ ) chromosome races was assessed by electrophoresis. A total of 289 shrews were used for the study. No clines of allele frequencies between the races studied were found. The genetic differentiation among the populations from the hybrid zone was relatively low, but statistically significant $\left(F_{S T}=0.015, p<0.001\right)$. The UPGMA tree illustrating genetic relationships among the five populations studied revealed that populations of the same chromosome categories were grouped together on the tree and populations of different chromosomal categories were well-separated. Most of the branches were supported by high bootstrap values $(>70 \%)$. However, the partial Mantel tests revealed no significant correlation between the genetic distance matrix and the chromosomal distance matrix. Furthermore, the effect of geographic distance and environmental barriers (moraines) on gene flow was not important. The absence of a relationship between genetic and chromosomal distance is probably due to low genetic differentiation between the $\mathrm{Dn}$ and $\mathrm{\iota g}$ races studied. The gene flow $(\mathrm{Nm}=16)$ among populations in the $\mathrm{Dn} / \mathrm{Lg}$ hybrid zone studied does not seem to be restricted.

University of Białystok, Institute of Biology, ul. Świerkowa 20 B, 15-950 Białystok, Poland, e-mail: ermi@cksr.ac.bialystok.pl

Key words: Sorex araneus, hybrid zone, chromosome races, gene flow

\section{Introduction}

The common shrew Sorex araneus Linnaeus, 1758 shows phenomenal chromosomal variability of the Robertsonian type. This variability results from chromosome fusions and whole arm reciprocal translocations (WARTs) (Searle 1984, Halkka et al. 1987, Volobouev and Catzeflis 1989). So far fifty chromosome races have been described all over the Palearctic range of S. araneus (Zima et al. 1996, Searle and Wójcik 1998). Each of these is characterized by a different set of Rb metacentrics. When different chromosome races come into contact, hybrid individuals are produced. Hybrid zones of the common shrew provide the opportunity to study the 
impact of chromosome differences on gene flow between distinct chromosome races. Chromosomal incompatibilities, eg hybrid unfitness due to chromosome unpairing and nondisjunction at meiosis I (for review see Searle 1993), may reduce genetic exchange between hybridizing races. However, to study genetic introgression from one race to another, markers other than the chromosomal rearrangements themselves should be used, as the chromosomal variants may be under selective forces. Selectively neutral markers, such as allozymes could be very valuable in the studies of hybrid zones in S. araneus. Unfortunately, the impressive karyotypic variation in the common shrew is not accompanied by corresponding genetic differentiation (Frykman et al. 1983, Catzeflis 1984, Searle 1985, Bengtsson and Frykman 1990, Wójcik and Wójcik 1994). The only differences in allele frequencies involve the Mpi-1 locus between the races in Sweden (Frykman et al. 1983) and diagnostic alleles for albumin and urinary pepsin loci for the Valais race in Switzerland (Neet and Hausser 1991). Additionally, the Valais race differs from other common shrew races with respect to the cytochrome $b$ gene sequence (Taberlet et al. 1994).

Two chromosomally distinct karyotypic groups of the common shrew are thought to have colonized Poland after the last glaciation: the Western European Karyotypic Group, WEKG (diagnostic metacentrics: $h i, g m$ ) and the Eastern European Karyotypic Group, EEKG (diagnostic metacentric: gr) (Searle 1984, Wójcik 1993). Chromosome races of the common shrew in Poland, even those which belong to different karyotypic groups, show no diagnostic genetic markers (Wójcik and Wójcik 1994, Ratkiewicz 1997). A lack of differentiation was also found for the cytochrome $b$ gene sequence for $S$. araneus in Poland, suggesting almost no genetic differentiation between the WEKG and EEKG (Ratkiewicz 1997). No significant divergence between populations within a single chromosome race has been found either (Banaszek et al. 1996, Ratkiewicz 1997). Nevertheless, it would be interesting to investigate genetic differentiation among populations in a hybrid zone between genetically similar races, which differ only with their set of metacentrics. Chromosomal incompatibilities may result in genetic differentiation among populations in such a hybrid zone. It could then be possible to consider the effect of chromosomes on gene flow. We have chosen the Drnholec/Legucki Młyn hybrid zone situated in northern Poland for this study. In this hybrid zone two different chromosome races come into contact: (1) the Łegucki Młyn race ( $\mathrm{kg}$ ) with diagnostic metacentrics $h k$, $i o, g r, m n$, which is present mainly in northern part of the zone, (2) the Drnholec race (Dn) with metacentrics $h i, k o, g m, n r$ which occupies the southern part of the transect studied (Fig. 1). In the centre of the zone complex heterozygotes forming four element ring complexes (RIV) and four or five element chain complexes (CV or CIV) at meiosis I are very numerous (Fedyk et al. 1991). The Dn/Lg hybrid zone was described incorrectly as the Stobnica / Łg hybrid zone in the past (Fedyk et al. 1991, Fedyk 1995, Szałaj et al. 1995) due to a mistake in chromosome arm identification and the incorrect description of chromosome $n r$ specific for the Dn race as chromosome $n p$ (Fedyk et al. 2000). 
In this study we present the results of an electrophoretic analysis of shrew populations in the Drnholec/Legucki Młyn hybrid zone between genetically similar races, which differ only on chromosomal grounds. We consider the effect of the chromosomal rearrangements themselves on gene flow. We also estimate the effect of geographic distance and geographic barriers (moraines) on gene flow.

\section{Material and methods}

The shrews were collected simultaneously at five different sites in June and September 1994. A total of 289 shrews were caught on the transect $31.7 \mathrm{~km}$ long along the Pasłęka and Jemiołówka river valleys in northern Poland (Fig. 1). The five sampling sites correspond to the five subzones described by Fedyk et al. (1991). The individuals under study were not karyotyped, as the chromosomal structure of the hybrid zone was well known (Fedyk 1995). We assumed that populations P1 and P5 were pure race populations of the $\mathrm{g}$ and Dn races, respectively. P2 was a population of the $\mathrm{g}$ race

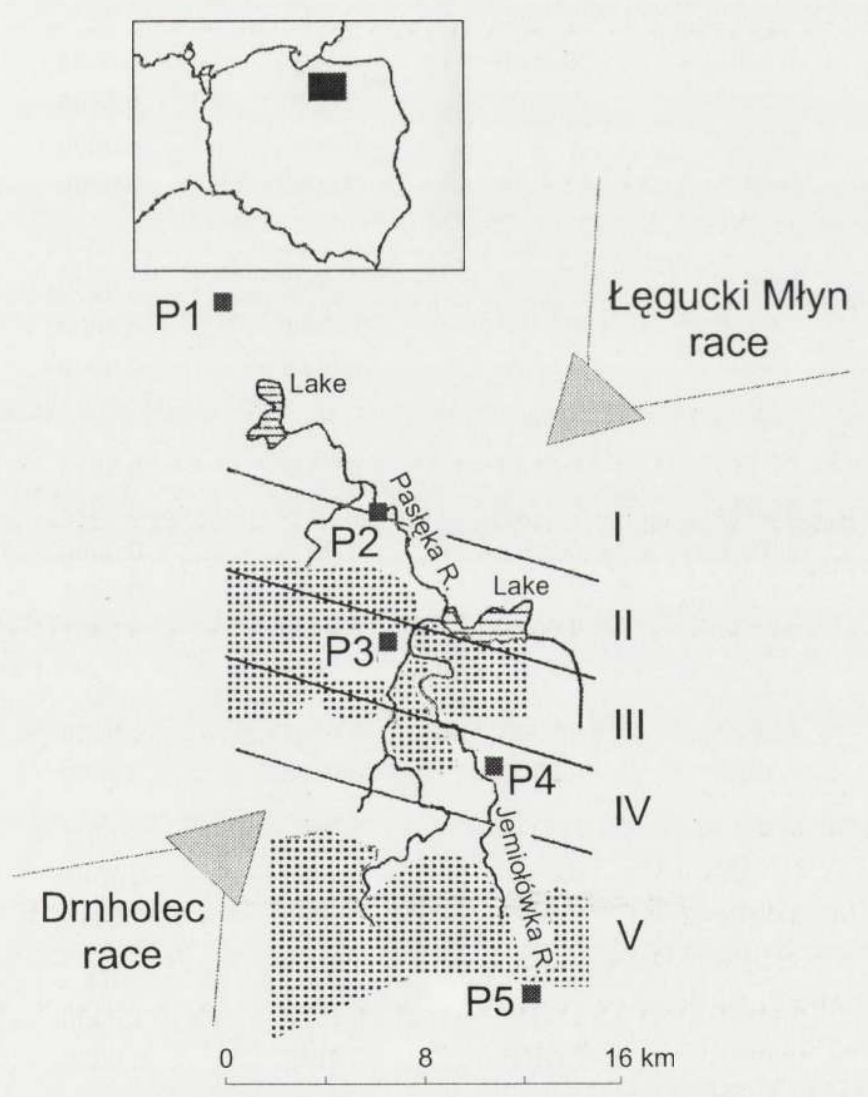

Fig. 1. Map of the study area. P1-P5 denote sampling sites, bold lines represent rivers, dotted areas represent moraines and fine lines separate the subzones (I-V) defined by Fedyk et al. (1991). 
Table 1. Allele frequencies for the polymorphic loci in the five populations of Sorex araneus studied. Sampling site codes according to Fedyk et al. (1991) given in parentheses. $n$-sample size.

\begin{tabular}{|c|c|c|c|c|c|c|}
\hline \multirow{2}{*}{$\begin{array}{l}\text { Locus } \\
\text { and alleles }\end{array}$} & \multicolumn{6}{|c|}{ Population and sampling site code } \\
\hline & & P1 (121) & P2 (33) & P3 $(16,93,96)$ & P4 (108) & P5 (101) \\
\hline$M p i$ & $n$ & 42 & 70 & 75 & 59 & 39 \\
\hline$A$ & & 0.7857 & 0.6857 & 0.8133 & 0.7797 & 0.8846 \\
\hline$B$ & & 0.1310 & 0.2214 & 0.1000 & 0.1949 & 0.0769 \\
\hline$C$ & & 0.0833 & 0.0929 & 0.0867 & 0.0254 & 0.0385 \\
\hline Acy & $n$ & 41 & 71 & 74 & 58 & 39 \\
\hline$A$ & & 0.7439 & 0.7958 & 0.7230 & 0.7155 & 0.7692 \\
\hline$B$ & & 0.1098 & 0.1056 & 0.1081 & 0.1121 & 0.0897 \\
\hline$C$ & & 0.1341 & 0.0915 & 0.1689 & 0.1724 & 0.1410 \\
\hline$D$ & & 0.0122 & 0.0070 & 0.0000 & 0.0000 & 0.0000 \\
\hline Est-1 & $n$ & 42 & 71 & 74 & 58 & 38 \\
\hline$A$ & & 0.5833 & 0.5986 & 0.7635 & 0.8534 & 0.6579 \\
\hline$B$ & & 0.3929 & 0.3732 & 0.2297 & 0.1466 & 0.3421 \\
\hline$C$ & & 0.0000 & 0.0211 & 0.0000 & 0.0000 & 0.0000 \\
\hline$D$ & & 0.0238 & 0.0070 & 0.0068 & 0.0000 & 0.0000 \\
\hline Pgm-1 & $n$ & 42 & 70 & 75 & 58 & 40 \\
\hline$A$ & & 0.9762 & 0.9786 & 0.9933 & 1.0000 & 0.9875 \\
\hline$B$ & & 0.0238 & 0.0143 & 0.0000 & 0.0000 & 0.0000 \\
\hline$C$ & & 0.0000 & 0.0071 & 0.0067 & 0.0000 & 0.0125 \\
\hline Pgm-3 & $n$ & 42 & 70 & 75 & 58 & 40 \\
\hline$A$ & & 0.7738 & 0.7643 & 0.8333 & 0.7845 & 0.8000 \\
\hline$B$ & & 0.2024 & 0.2214 & 0.1400 & 0.1293 & 0.1625 \\
\hline$C$ & & 0.0000 & 0.0071 & 0.0000 & 0.0000 & 0.0375 \\
\hline$D$ & & 0.0000 & 0.0000 & 0.0067 & 0.0431 & 0.0000 \\
\hline$E$ & & 0.0238 & 0.0071 & 0.0200 & 0.0431 & 0.0000 \\
\hline$L d h-2$ & $n$ & 42 & 71 & 75 & 60 & 39 \\
\hline$A$ & & 1.0000 & 0.9930 & 0.9867 & 1.0000 & 0.9744 \\
\hline$C$ & & 0.0000 & 0.0070 & 0.0133 & 0.0000 & 0.0256 \\
\hline$I d h-2$ & $n$ & 42 & 71 & 75 & 60 & 39 \\
\hline$A$ & & 0.6429 & 0.6901 & 0.7000 & 0.7583 & 0.8846 \\
\hline B & & 0.3571 & 0.3099 & 0.3000 & 0.2417 & 0.1154 \\
\hline$E s-D$ & $n$ & 42 & 71 & 75 & 60 & 39 \\
\hline$A$ & & 1.0000 & 1.0000 & 0.9733 & 1.0000 & 0.9744 \\
\hline$B$ & & 0.0000 & 0.0000 & 0.0267 & 0.0000 & 0.0256 \\
\hline Pgd & $n$ & $n 42$ & 71 & 74 & 58 & 39 \\
\hline$A$ & & 0.9524 & 0.9648 & 0.9527 & 0.9483 & 0.9615 \\
\hline$B$ & & 0.0476 & 0.0352 & 0.0473 & 0.0517 & 0.0385 \\
\hline
\end{tabular}


with low frequencies of hybrids. P3 and P4 were mixed populations with high frequencies of hybrids. Sample sizes varied from 40 to 76 individuals (Table 1). Both juvenile and adult shrews were present in the material. As the smallest distance between sampling sites was $5.7 \mathrm{~km}$, individuals from each of the five sites were regarded as a sample from a separate population. At every sampling site (P1-P5) shrews were trapped in four lines, each consisting of 20 pitfalls. If the distance between pitfall lines was more than 500 meters, we arbitrarily regarded such sample sets as subpopulations. Three subpopulations in the population P3 were considered. Two subpopulations were analysed in the remaining four populations. Populations $\mathrm{P} 1-\mathrm{P} 4$ were located along a continuum of habitats suitable for shrews. The moraines narrow the river valley down to 100-300 meters along a distance of about 3 $\mathrm{km}$ (between 18.8 and $22.4 \mathrm{~km}$ of the transect, Fig. 1). Another moraine is located to the south of the zone and separates population P5 from the other populations. These moraines may reduce dispersal of shrews.

Animals were killed in the laboratory and dissected. Kidney homogenates were used for the electrophoresis. The running conditions and staining followed Selander et al. (1971), Quavi and Kit (1980) and Searle $(1983,1985)$. Starch gel electrophoresis was performed for most of the enzymes, except for phosphomutase-1, -3 (PGM-1, -3) and mannose phosphate isomerase (MPI) for which cellulose acetate plates were used. A total of 22 isoenzymes, encoded by 31 loci was studied (Table 1 and 2). Alleles at the polymorphic loci were designated with letters ( $A$ for the most common) according to Searle $(1983,1985)$.

Calculations of allele frequencies, deviations from Hardy-Weinberg expectations, Nei's (1972) genetic distance and $F$-statistics were performed using the software package TFPGA (Miller 1997). $F$-statistics according to Weir and Cockerham (1984) were estimated for each polymorphic locus and over all loci. The effect of nonrandom mating on heterozygosity within populations was measured using the inbreeding coefficient $F_{I S}$. The fixation index $F_{S T}$ (unbiased estimate, $\theta$ ) was calculated to assess genetic differentiation among populations. One thousand bootstrap replicates over loci were used to generate $95 \%$ confidence intervals (C. I.) to test the null hypotheses $H_{0}, F_{I S}$ not $>0$ and $F_{S T}$ not $>$ 0 . As bootstrap tests may incorrectly indicate significant substructuring within populations when only a few loci are available, an exact test for population differentiation, using the Markov chain method was performed (Raymond and Rousset 1995). Jacknifing over loci provided an estimate of the standard error and average value of $F_{S T}$. This may allow aberrant loci to be detected, eg loci under evolutionary forces. The theoretical number of migrants entering every population per generation $(\mathrm{Nm})$ was estimated from $F_{S T}$ using the formula: $N m=\left(1-F_{S T}\right) / 4 F_{S T}$ for neutral alleles in an island model of subdivided populations at migration - drift equilibrium (Wright 1951). To investigate the effect of geographic distance, geographic barriers (moraines) and chromosomes on genetic distances we used Mantel tests (Mantel 1967, Manly 1997). Nei's (1972) genetic distances were calculated to generate a genetic distance matrix. The geographic distance matrix gives the distance (in kilometres) separating each population. The moraine matrix contains values corresponding to the number of moraines separating the samples. The chromosomal distance matrix was created using the frequencies of the race - diagnostic metacentrics analysed by Fedyk (1995). For example, in population P1 the frequency of io metacentric equals 0.80 , while in P2 this value equals 0.76 (Fedyk 1995), thus the chromosomal distance for io metacentrics, Dio equals $(0.80-0.76)=0.04$. The chromosomal distance was computed as the mean pairwise divergence race-diagnostic over all metacentrics. Mantel tests were performed for association between the genetic distance matrix (dependent matrix) and the three others. Because sampling was performed along a transect, the matrices of geographic distance, moraine distance and chromosomal distance are likely to be themselves correlated. Therefore, to eliminate spurious significant correlation with the genetic distance matrix, multiple matrices partial Mantel tests (Manly 1997) were performed. Multiple Mantel tests are frequently used in evolutionary biology (Thorpe 1996). The tests were also used in the another $S$. araneus hybrid zone (Lugon-Moulin et al. 1996, 1999). We used a Pascal translation of the FORTRAN code found in Manly (1991). Partial Mantel tests were done by regressing the distances in one matrix on the distances in two other matrices. A total of 10000 radomizations on rows and columns of the dependent distance matrix were carried out. As more than one partial Mantel test were performed, a Bonferroni correction (Sokal and Rohlf 1995) was applied, setting the probability level (Bonferroni - corrected) to $p=0.017(0.05 / 3)$. Additionally, cluster analysis using the UPGMA method was carried out on Nei's (1972) genetic distance $D$ matrix in order 
to see which of the populations being considered were close together and which are far apart on the genetic tree. This is therefore another way to study the relationships between two distance matrices (Manly 1997). Bootstrap analysis with 1000 replicates was performed to evaluate the support values for specific nodes in the tree. Genotypic disequilibria for a given pair of polymorphic loci within every population and for the whole sample were calculated using the software package of Garnier-Gere and Dillmann (1992). Probability values for the null hypothesis $H_{0}$ "linkage disequilibruim between a given pair of loci equals zero" were calculated.

\section{Results}

Out of 31 loci studied, 23 were monomorphic with the same allele fixed in all populations studied (Table 2). A few heterozygous individuals were found at esterase-D (Est-D) and lactate dehydrogenase-2 $(L d h-2)$. The aminoacylase (Acy), esterase-1 (Est-1), isocitrate dehydrogenase-2 (Idh-2), mannose phosphate isomerase $(\mathrm{Mpi})$, 6-phosphogluconate dehydrogenase $(P g d)$ and phosphoglucomutase-3 $(P g m-3)$ loci were found to be highly polymorphic (Table 1$)$. No deviations from Hardy-Weinberg expectations in any subpopulation or population were found. $F_{I S}$ values suggested no heterozygote deficit in the populations studied. An exact test for population differentiation showed no population substructuring in any population. All the populations might be regarded as random breeding units.

None of the alleles was diagnostic for the races studied. The only differences were for the rare alleles Est- $1^{C}, E s t-1^{D}, A c y-1^{D}$ and $P g m-1^{B}$ which were present in the populations of the $\mathrm{Lg}$ race exclusively, while the $P g m-3^{D}$ allele was absent in

Table 2. A list of monomorphic enzymes and corresponding loci in the five populations of Sorex araneus studied.

\begin{tabular}{|c|c|}
\hline Locus & Abbreviation \\
\hline Adenosine deaminase -1 & Ada-1 \\
\hline Aldolase & Ald \\
\hline Aspartate aminotransferase- $1,-2$ & Aat $-1,-2$ \\
\hline Catalase & Cat \\
\hline Diaphorase & Dia \\
\hline Fumarase & Fum \\
\hline Glucose phosphate isomerase & Gpi \\
\hline Glutamate dehydrogenase- $1,-2$ & Glud-1, -2 \\
\hline$\alpha$-Glycerophosphate dehydrogenase- 1 & $\alpha-G p d-1$ \\
\hline$\beta$-Glycerophosphate dehydrogenase $-1,-2$ & $\beta-G p d-1,-2$ \\
\hline Isocitrate dehydrogenase- 1 & $I d h-1$ \\
\hline Lactate dehydrogenase-1 & $L d h-1$ \\
\hline Malate dehydrogenase $-1,-2$ & $M d h-1,-2$ \\
\hline Malic enzyme-1 & $M e-1$ \\
\hline Purine nucleoside phosphorylase & $N p$ \\
\hline Peptidase-1 & Pep-1 \\
\hline Superoxide dismutase- $1,-2,-3$ & Sod-1, $-2,-3$ \\
\hline
\end{tabular}


Table 3. $F_{S T}$ and $F_{I S}$ values per locus as a measure of genetic differentiation among populations studied. Asterisks indicate significant values: ${ }^{*}-p<0.05$, ${ }^{* *}-p<0.01,{ }^{* * *}-p<0.001$.

\begin{tabular}{llr}
\hline Locus & \multicolumn{1}{c}{$F_{S T}$} & \multicolumn{1}{c}{$F_{I S}$} \\
\hline Mpi & $0.0160^{*}$ & 0.0728 \\
Acy & 0.0000 & 0.1163 \\
Est-1 & $0.0456^{* * *}$ & -0.0504 \\
Pgm-1 & 0.0051 & 0.0008 \\
Pgm-3 & $0.0035^{*}$ & -0.0139 \\
Ldh-2 & 0.0062 & 0.0067 \\
Idh-2 & $0.0210^{* * *}$ & 0.0203 \\
Es-D & $0.0165^{*}$ & -0.0085 \\
Pgd & 0.0000 & -0.0564 \\
Over loci & $0.0154^{* * *}$ & 0.0251 \\
\hline
\end{tabular}

populations P1 and P2 (Table 1). No abrupt clines of allele frequencies through the hybrid zone were found, either. However, exact tests for population differentiation revealed significant differences in allele frequencies for $M p i(p=0.013)$, Est-1 $(p<0.001), P g m-3(p=0.017), I d h-2(p<0.001)$ and $E s-D(p=0.026)$ among the five populations studied. $F_{S T}$ values for polymorphic loci are given in Table 3 . Jacknifing over all loci revealed that genetic differentiation for the Est-1 locus ( $F_{S T}$ $=0.046$ ) deviated significantly from the average $F_{S T}$ value. Genetic differentiation among the populations within the hybrid zone was fairly low (overall $F_{S T}=0.015$ ), but statistically significant (95\% C. I. from bootstrapping across loci: upper 0.0301 , lower $0.0004, p<0.05$; by an exact test: $p<0.001$ ). The average number of migrants per generation into every population was $\mathrm{Nm}=16$ individuals. Nei's (1972) genetic distance between populations is given in Table 4. An UPGMA tree illustrating the genetic relationships among the five populations studied revealed two groupings supported by high bootstrap values ( $>70 \%$, Fig. 2). A first branch consists of samples P1 and P2 (almost purely the $\mathrm{g} \mathrm{race)} \mathrm{and} \mathrm{occurred} \mathrm{in} 710$ of

Table 4. Matrix of Nei's (1972) genetic distance among five populations of Sorex araneus across the Dn/ $\mathrm{Lg}$ hybrid zone studied.

\begin{tabular}{lcccc}
\hline Population & P1 & P2 & P3 & P4 \\
\hline P1 & - & & & \\
P2 & 0.0022 & - & & \\
P3 & 0.0057 & 0.0054 & - & \\
P4 & 0.0127 & 0.0094 & 0.0008 & - \\
P5 & 0.0102 & 0.0078 & 0.0049 & 0.0076 \\
\hline
\end{tabular}




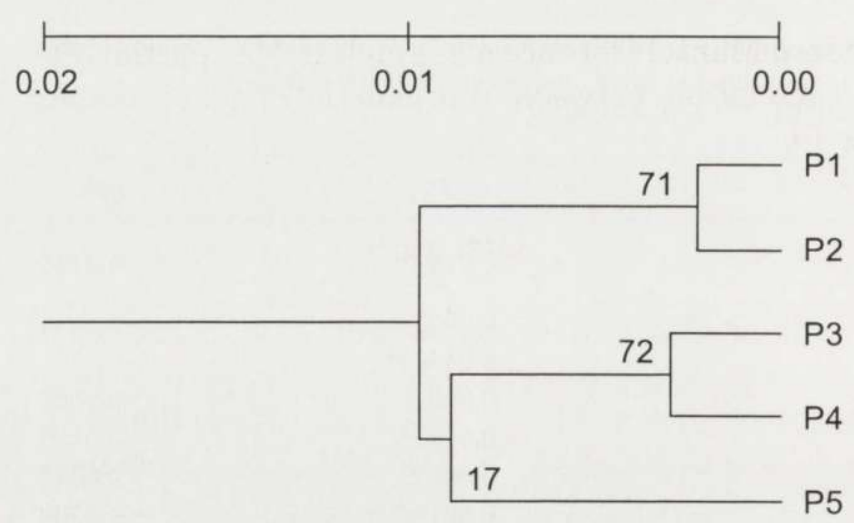

Fig. 2. UPGMA tree based on Nei's (1972) genetic distance between five populations (P1-P5) of Sorex araneus in the Drnholec/Łequcki Młyn hybrid zone. Numbers at the branches indicate bootstrap values based on 1000 replicates.

1000 trees generated by bootstrapping. The second branch, consists of samples P3 and P4 (populations with numerous hybrids) and had a bootstrap value of $72 \%$. The branch on the dendrogram with the sample P5 (the Dn race) shows low bootstrap support (17\%, Fig. 2).

No significant genotypic disequilibria were found for any pair of polymorphic loci within any population or for the whole sample. The hypothesis $H_{0}$ of independence of the loci studied could not be rejected.

The Mantel test showed no correlation between genetic distance and geographic distance ( $r=0.3525, \mathrm{~ns})$. On the other hand, the test showed significant correlation between genetic distance and chromosomal distance $(r=0.4763, p=0.03)$ and genetic distance and moraines $(r=0.5096, p=0.04)$. Because the geographic distance matrix and moraine matrix are correlated $(r=0.6686, p=0.037)$, and also the moraine matrix and chromosomal distance matrix are correlated $(r=0.9527$,

Table 5. Results of the partial Mantel tests from comparison of different distance matrices. The analysis is a partial regression Y. X. S., where Y is a dependent matrix, $\mathrm{X}$ and $\mathrm{S}$ are the variables that hold the distances that the regressed against the dependent matrix. $r$ - correlation coefficient, Gen genetic distance matrix, mor - moraine matrix, $\mathrm{km}$ - geographic distance matrix, chro - chromosomal distance matrix, $r$ - correlation coefficient between the matrices compared, $p$ - the probability that $r$ equals zero (no correlation between the matrices).

\begin{tabular}{lcc}
\hline Matrices compared & $r$ & $p$ \\
\hline Gen km mor & 0.5104 & 0.0521 \\
Gen km chro & 0.4805 & 0.0529 \\
Gen mor chro & 0.5107 & 0.0898 \\
\hline
\end{tabular}


$p=0.015)$ standard Mantel tests are meaningless. The partial Mantel tests showed no significant correlation between the genetic distance matrix and any other matrices (Table 5).

\section{Discussion}

We showed relatively little, albeit statistically significant, genetic differentiation between the Drnholec (WEKG) and Łęucki Młyn (EEKG) chromosome races on the transect $31.7 \mathrm{~km}$ long $\left(F_{S T}=0.015\right)$. This means that the five populations in the hybrid zone studied have diverged somewhat. On the contrary, in studies where hybrid zones were not considered, no significant interracial structuring was found (Banaszek et al. 1996, Ratkiewicz 1997). The genetic differentiation at the Est-1 locus deviated significantly from the average $F_{S T}$ value (Table 3 ), what might indicate that this locus is influenced by evolutionary forces in the hybrid zone. At the present moment, however, it is not possible to find the causes of slightly greater $F_{S T}$ value for this locus, as the chromosome localization for Est-1 is not known. We do not know, whether the Est-1 locus is located on the chromosome involved in a meiotic complex or not. Anyway, the $F_{S T}$ value for the Est-1 locus, similarly to the other polymorphic loci analysed, is still below the level of moderate genetic differentiation, ie $F_{S T}=0.05$, according to Wright (1978). Wójcik et al. (1996) have also found a relatively high $F_{S T}$ value for the Est-1 locus (0.027) in samples of the common shrew from three habitats in Białowieża, eastern Poland (the Białowieża race).

We investigated the possible causes of population differentiation in the $\mathrm{Dn} / \mathrm{Lg}$ hybrid zone revealed by this study. This differentiation might be due to specific environmental factors on the transect studied, as hybrid zones are often trapped by local barriers (Barton and Hewitt 1985), or due to hybrid unfitness. The results of Mantel test in our study showed no correlation between genetic distance and geographic distance $(r=0.3525, \mathrm{~ns})$. It means no isolation by distance at a scale of $31.7 \mathrm{~km}$. This is not surprising, as shrews are capable of movements of up to 4-5 kilometres, indicating a high potential to disperse (Tegelström and Hansen 1987). Similarly, no isolation by distance was found along a transect $7 \mathrm{~km}$ long in the Cordon/Valais hybrid zone in the Western Alps, using microsatellites (Lugon-Moulin et al. 1996). In the Dn/Lg hybrid zone, moraines were also found to be insignificant barriers for gene flow $(r=0.5104, \mathrm{~ns})$. This is slightly surprising, as Hatfield et al. (1992) suggested that uplands are less nutrient rich than lowlands and hence support a lower biomass of plants, insects and shrews. Shrews, however might migrate easily through or in the vicinity of moraines. Our results show that the effect of moraines as barriers to dispersal is weaker than expected. It could then be concluded that no significant environmental barrier for gene flow was present at the centre of this hybrid zone. Similarly, in the Cordon/Valais hybrid zone, mountain torrents and rivers were found to be weak barriers to gene flow (Brünner and Hausser 1996, Lugon-Moulin et al. 1996, 1999). No correlation was also found 
between the genetic distance matrix and chromosomal distance matrix (Table 5). This is in contrast with the results of the UPGMA analysis. The UPGMA tree illustrating genetic relationships among the five populations studied revealed that populations of the same chromosome categories were grouped together on the tree and populations of different chromosomal categories were well-separated (Fig. 2). Samples P1 and P2, which represent almost only the $Ł g$ race were a well-supported group of samples. Another well-supported branch was formed by P3 and P4 (populations with many hybrids). Results of the phylogenetic analysis (the topology of UPGMA tree) may suggest that chromosomal differences influence genetic differentiation among populations and gene flow in the hybrid zone. However, this influence is not very great, as genetic differentiation is rather low. In fact, the analysis of allozyme variation in the $\mathrm{Dn} / \mathrm{tg}$ hybrid zone showed that almost free genetic exchange among the populations studied $(\mathrm{Nm}=16)$ probably occurs in this zone. Despite the remarkable differences in chromosome arm combinations between the Dn and $\mathrm{g}$ races, the level of genetic divergence revealed by this study was not impressive. This is in agreement with previous data for chromosome races belonging to the WEKG and EEKG in Poland with regard to allozymes (Wójcik and Wójcik 1994, Ratkiewicz 1997) and cytochrome $b$ gene sequence (Ratkiewicz 1997). Wójcik (1993) in his model of karyotype evolution of the common shrew in Poland suggested the spread of different metacentrics over populations. If these populations were genetically homogenous, the weak differentiation found in this study could have mostly historical reasons. Chromosomal fusions characteristic for WEKG $(h i)$ and EEKG $(g r)$ may have been formed allopatrically in southern Europe during the last glacial maximum (20 000 to 15000 b.p., Searle 1984, Wójcik 1993). This would suggest quite a recent origin of the Dn (WEKG) and the $\mathrm{kg}$ (EEKG) races, and thus low genetic differentiation. Furthermore, little genetic differentiation along the transect studied was also expected due to the chromosomal structure of the $\mathrm{Dn} / \mathrm{Lg}$ hybrid zone. First, the gene flow in this hybrid zone is facilitated by the recombinant peak (Fedyk et al. 1991, Fedyk 1995). Second, at least one type of hybrid (RIV) has normal or near-normal fertility (Banaszek et al. $2000 \mathrm{a}, \mathrm{b})$ and the frequency clines of metacentrics forming the RIV complex probably reflect neutral diffusion. Moreover, Banaszek et al. (2000b) showed that in the $\mathrm{Dn} / \mathrm{Lg}$ zone reproductive performance is not seriously reduced in hybrid populations. In contrast to the Dn/Lg hybrid zone, in the Cordon/Valais hybrid zone the races do not show many chromosomal incompatibilites, but are genetically distinct and gene flow ( $\mathrm{Nm}=0.15$ migrants per generation) corresponds to the observed dispersal revealed by karyotypes (Brünner and Hausser 1996). For the Cordon/Valais hybrid zone, Brünner and Hausser (1996) postulated that the significant structure found for nuclear markers $\mathrm{Alb}$ and $\mathrm{Pg}$ is due to the different genetic constitution of the hybridizing races: Cordon and Valais. It may be concluded then, that genetic differences may have more pronounced effects on gene flow than chromosomal incompatibilities, at least in the hybrid zones where hybrids forming complexes up to five elements at meiosis I are found. Reduction of 
gene flow due to genetic differences between the Cordon/Valais races $(\mathrm{Nm}=0.15$, Brünner and Hausser 1996) may be even two orders greater than that due to chromosomal incompatibilities ( $\mathrm{Nm}=16$, this study). Therefore, for the common shrew it could be a rule that genetic differences among races have a stronger effect on gene flow than chromosomal differences. The recent origin of chromosome races in the common shrew suggested by Taberlet et al. (1994) and data from hybrid zones in the Western Alps (Brünner and Hausser 1996, Lugon-Moulin et al. 1999) corroborate with this hypothesis. However, the interpretation of allozyme data from the Dn/tg hybrid zone must be viewed as tentative, before more advanced analyses based on highly variable markers, eg microsatellites, are conducted.

Acknowledgements: We thank A. Radulska, K. Fedyk and D. Ochrymiuk for their invaluable help in the field. We also thank J. Hausser for helpful comments on the manuscript and J. B. Searle for improving our English. This work was supported by the Polish Scientific Committee (KBN grant No. 6P04C 06309 to M. Ratkiewicz and 6P204 03405 to S. Fedyk).

\section{References}

Banaszek A., Fedyk S., Szałaj K. A. and Chętnicki W. 2000a. A comparison of spermatogenesis in homozygotes, simple Robertsonian heterozygotes and complex heterozygotes of the common shrew (Sorex araneus). Heredity, in press.

Banaszek A., Fedyk S., Szałaj K. A. and Chętnicki W. 2000b. Reproductive performance in two hybrid zones between chromosome races of the common shrew Sorex araneus in Poland. [In: Evolution in the Sorex araneus group: Cytogenetic and molecular aspects. J. B. Searle and J. M. Wójcik, eds]. Acta Theriologica 45, Suppl. 1: 69-78.

Banaszek A., Ratkiewicz M., Fedyk S., Szałaj K. A. and Chętnicki W. 1996. The chromosomes and isoenzymes in marginal populations of the common shrew (Sorex araneus) in the Vistula delta. Zeitschrift für Säugetierkunde 61: 65-72.

Barton N. H. and Hewitt G. M. 1985. Analysis of hybrid zones. Annual Review of Ecology and Systematics 16: 113-148.

Bengtsson B. O. and Frykman I. 1990. Karyotype evolution: evidence from the common shrew (Sorex araneus L.). Journal of Evolutionary Biology 3: 85-101.

Brünner H. and Hausser J. 1996. Genetic and karyotypic structure of a hybrid zone between the chromosomal races Cordon and Valais in the common shrew, Sorex araneus. Hereditas 125: $147-158$.

Catzeflis F. 1984. Systématique biochemique, taxonomie et phylogénie des Musaraignes d'Europe (Soricidae, Mammalia). Ph D Thesis, Universite de Lausanne, Switzerland: 1-164.

Fedyk S. 1995. [Geographic chromosomal differentiation and hybrid zones between chromosome races of Sorex araneus in north-eastern Poland]. Dissertationes Universitatis Varsoviensis 439, Białystok: 1-125. [In Polish]

Fedyk S., Banaszek A., Chętnicki W., Cichomska A. and Szałaj K. A. 2000. Reassessment of the range of the Drnholec race: studies on meiosis in Sorex araneus hybrids. [In: Evolution in the Sorex araneus group: Cytogenetic and molecular aspects. J. B. Searle and J. M. Wójcik, eds]. Acta Theriologica 45, Suppl. 1: 59-67.

Fedyk S., Chętnicki W. and Banaszek A. 1991. Genetic differentiation of Polish populations of Sorex araneus L. III. Interchromosomal recombination in a hybrid zone. Evolution 45: 1384-1392.

Frykman I., Simonsen V. and Bengtsson B. O. 1983. Genetic differentiation in Sorex. I. Electrophoretic analysis of the chromosome races of Sorex araneus in Sweden. Hereditas 99: 279-292. 
Garnier-Gere P. and Dillman C. 1992. A computer program for testing pairwise linkage disequilibria in subdivided populations. Journal of Heredity 83: 239.

Halkka L., Söderlund V., Skarén U and Heikkilä J. 1987. Chromosomal polymorphism and racial evolution of Sorex araneus L. in Finland. Hereditas 106: 257-275.

Hatfield T., Barton N. and Searle J. B. 1992. A model of a hybrid zone between two chromosomal races of the common shrew (Sorex araneus). Evolution 46: 1129-1145.

Lugon-Moulin N., Brünner H., Balloux F., Hausser J. and Goudet J. 1999. Do riverine barriers, history or introgression shape the genetic structuring of a common shrew (Sorex araneus) population? Heredity 83: 155-161.

Lugon-Moulin N., Wyttenbach A., Brünner H., Goudet J. and Hausser J. 1996. Study of gene flow through a hybrid zone in the common shrew (Sorex araneus) using microsatellites. Hereditas 125: 159-168.

Manly B. F. J. 1997. Randomization, bootstrap and Monte Carlo methods in Biology. 2nd edition. Chapman and Hall, London: 1-399.

Mantel N. 1967. The detection of disease clustering and a generalized regression approach. Cancer Research 27: 209-220.

Miller M. P. 1997. Tools for population genetic analyses (TFPGA) 1.3: A Windows program for the analysis of allozyme and molecular population genetic data. Computer Software distributed by author.

Neet C. R. and Hausser J. 1991. Biochemical analysis and determination of living individuals of the Alpine chromosome races and species of the Sorex araneus group. Mémoires de la Société Vaudoise des Sciences Naturelles 19: 97-107.

Nei M. 1972. Genetic distance between populations. The American Naturalist 106: 283-292.

Quavi H. and Kit S. 1980. Electrophoretic patterns of aminoacylase-1 (Acy-1) activity. Biochemical Genetics 18: 669-679.

Ratkiewicz M. 1997. [Genetic consequences of karyotype divergence in Sorex araneus Linnaeus, 1758, revealed by isoenzymes and mitochondrial DNA]. Ph D Thesis, Warsaw University, Białystok Branch, Białystok: 1-85. [In Polish]

Raymond M. and Rousset F. 1995. An exact test for population differentiation. Evolution 49: $1280-1283$.

Searle J. B. 1983. Robertsonian chromosomal variation in the common shrew Sorex araneus L. Ph D Thesis, University of Aberdeen, Aberdeen.

Searle J. B. 1984. Three new chromosome races of the common shrew Sorex araneus (Mammalia, Insectivora) and a phylogeny. Systematic Zoology 33: 184-194.

Searle J. B. 1985. Isoenzyme variation in the common shrew (Sorex araneus) in Britain, in relation to karyotype. Heredity 55: 175-180.

Searle J. B. 1993. Chromosomal hybrid zones in eutherian mammals. [In: Hybrid zones and the evolutionary processes. R. G. Harrison, ed]. Oxford University Press, New York: 309-353.

Searle J. B. and Wójcik J. M. 1998. Chromosomal evolution: the case of Sorex araneus. [In: Evolation of shrews. J. M. Wójcik and M. Wolsan, eds]. Mammal Research Institute, Polish Acadeny of Sciences, Białowieża: 219-268.

Selander R. K., Smith M. H., Yang S. Y., Johnson W. E. and Gentry J. B. 1971. Biochenical polymorphism and systematics in the genus Peromyscus. I. Variation in the old-field mouse (Peromyscus polionotus). Studies in Genetics VI; The University of Texas Publications 7103: 49-90.

Sokal R. P. and Rohlf F. J. 1995. Biometry. 3rd edition. Freeman, San Francisco: 1-888.

Szałaj K. A., Fedyk S., Banaszek A. and Chętnicki W. 1995. Maximization of the frequency of recombinants in the hybrid zone of Sorex araneus in northern Poland. Acta Theriologice 40: 225-236.

Taberlet P., Fumagalli L. and Hausser J. 1994. Chromosomal versus mitochondrial DNA evoluiion: Tracking the evolutionary history of the southwestern European populations of the Sorex arazeus group (Mammalia, Insectivora). Evolution 48: 623-636. 
Tegelström H. and Hansen L. 1987. Evidence of long dispersal in the common shew (Sorex araneus). Zeitschrift für Säugetierkunde 52: 52-54.

Thorpe R. S. 1996. The use of DNA divergence to help determine the correlates of evolution of morphological characters. Evolution 50: 524-531.

Volobouev V. T. and Catzeflis F. 1989. Mechanisms of chromosomal evolution in three European species of the Sorex araneus-arcticus group (Insectivora: Soricidae). Zeitschrift für Zoologische Systematik und Evolutionsforschung 27: 252-262.

Weir B. S. and Cockerham C. C. 1984. Estimating $F$-statistics for the analysis of population structure. Evolution 38: 1358-1370.

Wójcik J. M. 1993. Chromosome races of the common shrew Sorex araneus in Poland: a model of karyotype evolution. Acta Theriologica 38: 315-338.

Wójcik J. M. and Wójcik A. M. 1994. Protein variation in the common shrew (Sorex araneus L.) in Poland, in relation to karyotype. Folia Zoologica 43, Suppl. 1: 53-61.

Wójcik J. M., Wójcik A. M. and Zalewska H. 1996. Chromosome and allozyme variation of the common shrew, Sorex araneus, in different habitats. Hereditas 125: 183-189.

Wright S. 1951. The genetical structure of populations. Annals of Eugenics 15: 323-354.

Wright S. 1978. Evolution and the genetics of populations, Vol. 4. Variability within and among natural populations. The University of Chicago Press, Chicago and London: 1-580.

Zima J., Fedyk S., Fredga K., Hausser J., Mishta A., Searle J. B., Volobouev V. T. and Wójcik J. M. 1996. The list of the chromosome races of the common shrew (Sorex araneus). Hereditas 125: 97-107.

Received 27 September 1999, accepted 8 February 2000. 